\title{
The Effect of Competence and Compensation on Employee's Performance in Transportation Department Provincial of South Sulawesi
}

\author{
Indira Basalamah \\ STIE Wira Bhakti Makassar, Indonesia \\ Graduate Student Moeslim Indonesian University, Indonesia \\ Indira_Basalamah@Yahoo.co.id
}

\begin{abstract}
Transportation Department Provincial of South Sulawesi which has 365 employees is a government institution in a unit within the government of Makassar City in the field of transportation service. The purpose of this study is to analyze the influence of competence and compensation on employee performance. This study uses a causal approach and to analyze the influence of independent variables (knowledge, skill, attitudes, and experience) on the dependent variable (employees performance) using data quality test methods, classical assumption test, descriptive statistical test, multiple regression test and hypothesis test. The structured reseach questionnaires to 78 respondents, the result of research suggests that all independent variables simultaneously have a positive and significant effect on employee performance and significant effect on employee performance and partially skilled variable (X2) is the most dominant variable has a positive and significant influence on the transportation department of South Sulawesi Province.
\end{abstract}

Keywords: Knowledge, skill, attitude, traits, financial compensation, non financial compensation, and Employee performance

\section{Introduction}

As a government agency that prioritizes public services, always try to improve the performance of employees as a whole. The role of human resources is the agency's main asset to create efficiency, effectiveness, and productivity. Effective human resources requires the leadership to find the best way to utilize the people in the organization environment so that the desired goals can be achieved. A well-maintained and growing performance will have a positive impact on the organization to improve and increase the public trust of users of public facilities and institutional benefits sustainably. However, performance does not automatically build but must be based on a strong foundation in order to survive the competition and dynamics of globalization. The main pillars to build employee performance include the competence of employees and fair and reasonable compensation. Competence-based human resources can increase capacity and build foundation because if the people who work in the organization have the right competence in accordance with the demands of his work, then the skills and mental and productive character (Istijanto, 2006). Each employee has the knowledge, abilities / skills, attitudes, and dispositions that vary according to the background of his life. With strong ownership of value, they will always be ready for change in accordance with the demands of the organization without losing its identity. Determination of the required competencies will certainly be used as a basis for performance evaluation of employees. Improving employee performance on an individual basis will compensate for overall HR performance (Muneer et al., 2016).

Compensation is one of the execution of HR functions that relate to all kinds of individual award giving as an exchange in performing organizational tasks. The compensation program can be divided into two groups based on the form of compensation and the manner in which it is granted. Compensation is divided into financial compensation (financial compensation) and nonfinancial compensation (nonfinancial compensation). According to the method of giving the compensation can be divided into direct compensation (direct compensation) and indirect compensation (indirect compensation). The use and application of appropriate and effective compensation will have a significant effect on the organization. When compensation is properly and appropriately targeted, employees will be more satisfied and motivated to achieve organizational goals (Abdullah, 2014). Department of Transportation of South Sulawesi Province as one of the government work unit which concentrate on transportation service field has civil servant status is required to have high performance in providing service for society. Achievement of high performance as a form of professionalism indicates the role of indicators such as employee competence and compensation has been done well. However, in this institution there is still a considerable gap in justice and equity. Traditional 
compensation systems adopted by class, rank, and minority. Compensation for employees has not been able to balance organizational goals and personal goals (Tufail et al., 2016).

Employees are always required to work and contribute more in the job but performance appraisal performance standards have not been applied. Only employees with functional positions have the opportunity to compensate financially and nonfinancial. Suwanto and Priansa (2014) stated that in reality it is difficult to establish a compensation that is really adequate, this is because the absence of a method most appropriate. In determining the compensation must be adjusted to the conditions and demands relating to internal and external consistency. The phenomenon made the Department of Transportation of South Sulawesi province to make improvements to improve performance through the determination of compensation standards based on competence. When an organization decides the application of a competency-based system, it takes significant time investment and management commitment. Because competency plans focus on the growth and development of employee competencies, employees who continue to develop their competencies also benefit from receiving a fair and marvelous raise.

\section{Literature Review}

Competence in the inner part of every human being and forever exists in the personality of a person who can predict behavior and performance extensively on all work situations and tasks. Spencer \& Spencer (1993) defines competence as a basic characteristic of a person with regard to the effectiveness of individual performance in his work. The basic characteristics of a person who identifies the way of thinking, acting, and acting and drawing conclusions that can be done and maintained by a person at any given time. The steps to determine the competence of a particular job position need to determine the specific functions of a position (function of job), learn how activities in the process of doing the task (activity or process), and determine what competencies are needed in the position. The purpose of the need in determining the level of a person's competence is to know the level of performance of the person in doing a job. Moeheriono (2014) suggests that everyone has some basic competencies: (1). Traits, which makes a person have attitude or behavior how people respond to something in a certain way, such as self-confidence, self-control, hardiness or hardiness (2). Motive, which is something that one wants or is consistently thought of and desired that results in an action. (3). Self-concept is the attitude and values that a person has or what attracts a person to do something. (4). Knowledge, is information possessed by a person in a particular field, (5) Skill, that is the ability to perform tasks physically and mentally mentally. In individual competencies can be grouped into (1) Competence threshold or minimum competence must possess a person that is the ability pengatahuan or basic skills, (2) Competence differentiating the competencies that distinguish a high-performing person at au low with other employees.

Competence of knowledge and skills is easier to develop through education and training programs for employees who are considered less competent. While the competence of self-concept, character and motives are in personality iceberg, more hidden so quite difficult to be developed, and to find out through psychologist with interview test. In detail, there are five dimensions of competency that must be owned by all employees individually, (1) Task skills, is skills to perform routine tasks in accordance with workplace standards, (2) Task management skills are skills to manage a series of tasks (3) Contigency management skill are learning to take quick and precise action when a problem arises in a job. (4) Job role enviroment skills, is skills to cooperate and maintain work environment comfort, (5) Transfer of skill is the skills to adapt to the new work environment.

Compensation is something an employee receives as a substitute for the contribution of their services to the company (Zainal et al., 2014). Compensation is an important factor affecting how and why people work in an organization and not in other organizations. Employee compensation also refers to all forms of payment or rewards for employees and comes from their work (Dessler, 2007). The compensation program can be divided into two major groups namely based on the form of compensation and the manner of payment. Based on the form, compensation is divided into financial compensation and nonfinancial compensation. Meanwhile, according to how the payment is divided into direct compensation and indirect compensation. Direct compensation consists of basic salary, performance payments, incentives (commissions, bonuses, profit share, stock options), retirement savings, and cumulative shares. Indirect compensation includes 
protection (insurance, severance pay, further studies, children's schools, pilgrimage, retirement), off-hours compensation (overtime, holiday, sick leave, maternity leave), and facilities (moving costs, vehicle). Nonfinancial Compensation includes reward for career (position, promotion opportunity, recognition of work, new findings, special achievements) and work environment (praise, friendly, comfortable duty, fun, and conducive). If managed well, compensation will help the agency to achieve its goals and obtain, maintain, and keep employees well. Conversely, without sufficient compensation, existing employees are very likely to leave the agency and to reassign it is not easy. The compensation system has an impact on job satisfaction and also affects the retention rate of employees (Nawab \& Bhatti, 2011). Compensation in the form of financial and non-financial rewards is a tool for achieving job satisfaction and is able to motivate and retain employees as human capital to achieve competitive competitive organization (Osibanjo et al., 2014).

Performance is a description of the level of achievement of the implementation of an activity or policy program in realizing organizational goals, objectives, vision and mission as outlined through strategic planning of an organization (Moeheriono, 2014). Mangkunegara (2004) defines performance as a result of work in quality and quantity achieved by an employee in performing its duties according to the responsibilities given to it. Suwanto and Priansa (2014) define performance as a result achieved by a person according to the applicable size, within a certain period of time concerning the work and its behavior and actions. The determination of performance indicators should ideally meet the following requirements: consistency, comparability, clarity, controllability, contigency, comprehensiveness, boundedness, relevance, and feasibility. Companies will always improve their productivity through consistency of delivering the best performance and maintaining the competitive advantage of the organization. The factor in providing competitive advantage for agencies is human resources, as well as related to how to manage these resources (Muneer et al., 2014).

Conceptual Framework: For ease of understanding, it can be frame of the study as followa:

Figure 1: Conceptual Framework Research

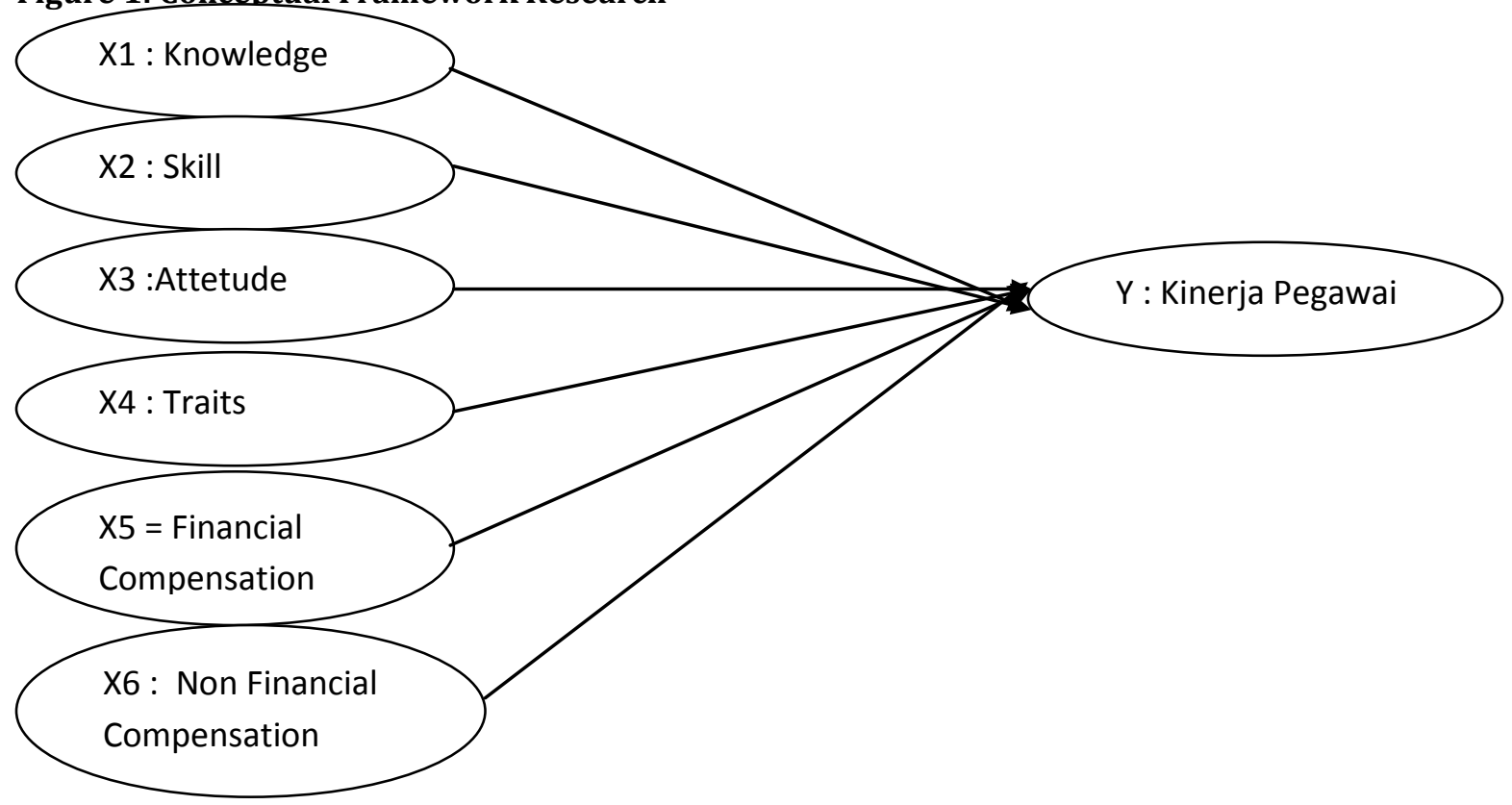

\section{Methodology}

This type of research used in this research is Quantitative Descriptive Analysis. This research was conducted at Transportation Department Provincial of South Sulawesi. The sample used was 78 respondent from the total population of 365 employees. This analysis is used Multiple Liner regression is formulated as follows:

$\mathrm{Y}=\mathrm{b} 0+\mathrm{b} 1 \mathrm{X} 1+\mathrm{b} 2 \mathrm{X} 2+\mathrm{b} 3 \mathrm{X} 3+\mathrm{b} 4 \mathrm{X} 4+\mathrm{B} 5 \mathrm{X} 5+\mathrm{b} 6 \mathrm{X} 6+\mathrm{e}$ 
$\mathrm{Y}=$ Employees' performance

$\mathrm{B} 0=$ Constant

$\mathrm{X} 1=$ Knowlwdge

$\mathrm{X} 2=$ Skill

$\mathrm{X} 3=$ Attetude

$\mathrm{X} 4=$ Traits

$\mathrm{X} 5$ = Finansial Compensation

$\mathrm{X} 5$ = Non-finansial Compensation

$\mathrm{B} 1, \mathrm{~b} 2, \mathrm{~b} 3, \mathrm{~b} 4, \mathrm{~b} 5, \mathrm{~b} 6=$ regression Coefficients

$\mathrm{E}=$ variable bully

The variable used in this study include the independent variable, the variable suspected as the cause dependent variable. In this case the independent variable is the competence and compensation, consists of Knowlwdge (X1), Skill (X2), Attitudes (X3), Traits (X4), Financial Compensation (X5), Non-financial Compensation (X6). 2. The dependent variable in this study is Employee Performance (Y)

\section{ResultS and Discussion}

The simultaneous test ( $\mathrm{F}$ test) is conducted to find out whether all independent variables $\mathrm{X}$ simultaneously have a significant influence on the dependent variable of employee performance (Y).

Table 1: Determination Analysis Model Summary

\begin{tabular}{|c|c|c|c|c|c|c|c|c|c|}
\hline Model & $\mathbf{R}$ & $\begin{array}{l}\mathrm{R} \\
\text { Square }\end{array}$ & $\begin{array}{l}\text { Adjusted } \\
\text { R Square }\end{array}$ & $\begin{array}{l}\text { Std. Error } \\
\text { of the } \\
\text { Estimate }\end{array}$ & $\begin{array}{l}\text { Change Stat } \\
\text { R Square } \\
\text { Change }\end{array}$ & $\begin{array}{l}\text { tistics } \\
\text { F } \\
\text { Change }\end{array}$ & df1 & df2 & $\begin{array}{l}\text { Sig. } \\
\text { Change }\end{array}$ \\
\hline 1 &. $.860^{\mathrm{a}}$ & .730 & .717 & .26193 & .739 & 33.484 & 6 & 71 & .000 \\
\hline
\end{tabular}

a. Predictors: (Constant), Knowledge, Skill, Attitude, Traits, financoal Compensation, Non-Financial Compensation

Source : Data, 2016

The data shows that the value of correlation coefficient (R) of 0.860 can be interpreted that there is a positive relationship and direction between variable $\mathrm{X}$ with variable $\mathrm{Y}$. Value $\mathrm{R} 2=0.730$. This means, the influence of variable $X$ (knowledge, skill, attitude, traits, financial compensation and non financial compensation) simultaneously to variable $Y$ (employee performance) is $73 \%$ and other variable influence $27 \%$. This effect is very good because it is greater than $60 \%$ and significant (Pvalue) $=0,000$.

\section{Table 2: Regression Coefficients Coefficients ${ }^{\mathrm{a}}$}

\begin{tabular}{|c|c|c|c|c|c|}
\hline \multirow[b]{2}{*}{ Model } & \multicolumn{2}{|c|}{$\begin{array}{l}\text { Unstandardized } \\
\text { Coefficients }\end{array}$} & \multicolumn{2}{|c|}{$\begin{array}{l}\text { Standardized } \\
\text { Coefficients }\end{array}$} & \multirow[b]{2}{*}{ Sig. } \\
\hline & B & Std. Error & Beta & $\mathbf{T}$ & \\
\hline (Constant) & -2.012 & .483 & & -4.164 & .000 \\
\hline Knowledge & .259 & .088 & .244 & 2.936 & .004 \\
\hline Skill & .370 & .096 & .313 & 3.838 & .000 \\
\hline Attitude & .184 & .082 & .167 & 2.248 & .028 \\
\hline Traits & .199 & .083 & .181 & 2.388 & .020 \\
\hline $\begin{array}{l}\text { Financial } \\
\text { Compensatiomm }\end{array}$ & .175 & .083 & .152 & 2.117 & .038 \\
\hline $\begin{array}{l}\text { Kompensasi } \\
\text { NonFinansial }\end{array}$ & .228 & .086 & .204 & 2.648 & .010 \\
\hline
\end{tabular}

a. Dependent Variable: employee performances, Source : data 2016 
Partially indicate that skill variable have positive and significant influence to employee performance at Transportation Department of South Sulawesi Province. This is shown in the acquisition of t-count value of 3.838 with a significant level of 0,000 which means $38.38 \%$ of employees have the skills or skills in the form of the ability to perform tasks physically and mentally.

The regression equation is formulated as follows :

$Y=-2,012+0,259 X_{1}+0,370 X_{2}+0,184 X_{3}+0,199 X_{4}+0,175 X_{5}+0,228 X_{6}$

The multiple regression equation can be explained as follows: The coefficient $b 0=-2,012$ means that if the independent variable $(\mathrm{X})$ does not change (constant), then the performance of employee (Y) at Transportation Department of South Sulawesi Province will decrease. The coefficient b1 $=0,259$ means If knowledge (X1) is improved, it is expected to improve employee performance (Y) at $25.9 \%$. The coefficient b2 $=0,370$ means that each skill variable $(\mathrm{X} 2)$ is improved, it is expected to improve employee performance $(\mathrm{Y})$ by $37 \%$. The coefficient $b 3=0,184$ shows any increase of attitude variable (X3), hence expected to improve employee performance (Y) equal to $18,4 \%$. Coefficient $b 4=0,199$ means every character of traits (X4) is improved, hence expected performance of employee $(\mathrm{Y})$ increase equal to $19,9 \%$. Coefficient $\mathrm{b} 5=0,259$ means employee performance will increase by $25,9 \%$ if institution pay attention to increase of Employee's Financial Compensation. The coefficient b6 $=0.228$ means that if the agency also paid attention to the award of non-financial compensation of employees, it is expected that its performance will increase by $22.8 \%$.

The results of multiple regression analysis from the results of this study indicate that all independent variables studied consist of knowledge variables (X1), skill (X2), attitude (X3), trait (X4), financial compensation (X5) and non-financial compensation (X6) simultaneously have a positive and significant effect on employee performance at Transportation Department of South Sulawesi Province. Of the six variables, the skill variable (X2) is the most dominant variable has a positive and significant effect on the performance of employees at the Transportation Department of South Sulawesi Province. The variables of knowledge have positive and significant effect on the performance of the employees at the Transportation Department of Sulawesi Province. Technological innovation, changes in the structure and processes within the organization so that employees must work fast. Consequently someone will learn continuously and competence development will be important to improve (Sonnentag \& Frese, 2001). The process of analytical thinking, conceptual thinking, knowledge of work and level of knowledge is an integrated and synergistic unit capable of forming effective performance. The skill variable has a positive and significant effect on the performance of the employees at the Transportation Department of South Sulawesi Province. Moeheriono (2014) suggests that skills as one of the characteristics of competence predict or lead to an effective performance. The results of this study are also in accordance with the statement of Zainal, et al (2014) that the ability and skills are the main factors affecting the behavior and performance of individuals. Skill variables through information disclosure, proactivity, attention to task clarity, and ability to influence are synergistic entities capable of effective performance.

The result of regression analysis shows that attitude / behavioral variables have positive and significant effect on employee performance at Transportation Department of South Sulawesi Province. How to develop others, directing skills, teamwork and leading the group is an indicator that can shape employee performance. Sonnentag and Frese (2001) say the success of the organization is demonstrated by the achievement of teamwork performance. Similarly, the variable traits of a person who has a positive and significant effect on the performance of employees at the Department of Transportation of South Sulawesi Province. Moeheriono (2014) argues that the character possessed by each individual has a behavioral attitude to respond to things in a certain way. This is reflected in self-confidence, self-control, a sense of fortitude and patience in the face of increasingly fast and precise demands of work. Financial Compensation and Non-financial Compensation Variables also have a positive and significant effect on employee performance. Giving merit pay is a payment system that correlates rewards with work performance of an employee (performance) .Implikasinya that someone who has a good performance, then he will get higher compensation and vice versa. That is, the higher the performance of employees will be higher the increase in compensation.

\section{Conclusion and Recommendations}

Result of research and discussion that has been described, it can be concluded as follows: 
- There is a strong relationship between competence and compensation on employee performance at the Transportation Department of South Sulawesi Province.

- Simultaneously, all competence and compensation variables have a positive and significant effect on employee performance at Transportation Department of South Sulawesi Province.

- Partially, the skill variables or expertise possessed by the most dominant individuals affect the performance of employees. This is the basis of the importance of institutions to develop training programs continuously in order to increase employee performance.

- If the agency does not attempt to improve the competency and compensation variables of its employees, then the performance of its employees will decrease.

- For the next researcher there are still some variables that have relationship with improvement of employee performance, for example about engagement which theoretically have the potential to improve employee performance.

\section{References}

Abdullah, M. (2014). Employee Performance Management and Evaluation. Aswaja Pressindo. Yogyakarta. Dessler, G. (2007). Human Resource Management. Indeks. Jakarta.

Istijanto. (2006). Riset Sumber Daya Manusia. PT. Gramedia Pustaka Utama. Jakarta.

Mangkunegara, A. P. (2004). Human Resource Management Coorporate. PT. Remaja Rosdakarya. Bandung.

Moeheriono. (2014). Competency Based Performance Measurement. PT. Rajagrafindo Persada. Jakarta.

Muneer, S., Jahanzeb, A. \& Suwandi. (2016). Income diversification and performance: a comparison of commercial and Islamic banks of Pakistan. Abasyn Journal of Social Sciences, Special Issue, 471-485

Muneer, S., Iqbal, S. M. J., Khan, S. U. \& Long, C. S. (2014). An Incorporated Structure of Perceived Organizational Support, Knowledge-Sharing Behavior, Organizational Trust and Organizational Commitment: A Strategic Knowledge Management Approach. Pakistan Journal of Commerce and Social Sciences, 8(1), 42- 57.

Nawab, S. \& Bhatti, K. K. (2011). Influence of Employee on Organizational Commitment and Job Satisfaction. A Case Study of Educational of Pakistan. International Journal of Business and Social Science, 2(8).

Osibanjo, O. A., Adenike, A. A., Hezekiah, O. F. \& Princess, T. H. (2014). Compensation Packages: A Strategic Tool for Employees' Performances and Retention. Leonardo Journal of Sciences, 25, 65-84

Sonnentag, S. \& Michael, F. (2001). Performance Concepts and Performance Theory. Psychological Management of Individual Performance. Jhon Wiley \& Son, Ltd.

Spencer, L. M. \& Spencer, S. M. (1993). Competence at work : Models for Superior performance, New York : Jhon Wiley \& Son.

Suwanto, H. \& Priansa, D. J. (2014). Human Resource Management in Organizations. Alfabeta. Bandung.

Tufail, M. S., Muneer, S. \& Ishtiaq, M. (2016). Job Characteristics with Task and Contextual Performance: Moderating Role of Procedural Justice for Front Line Managers. Journal of Social Sciences, Special Issue, 299-508.

Zainal, V. R., Salim, B. \& Natsir, M. (2014). Islamic Human Capital. Raja Grafindo Persada. Jakarta. 